\title{
The Relationship between Management's Commitment with Job Satisfaction According to Shari'ah-Based QMS (MS1900:2014) at Malaysian Higher Education Institution
}

\author{
Hj. Hasan Al-Banna bin Mohamed, Mohd Hamran Mohamad, Siti Arni Basir, Norlaila Mazura \\ Mohaiyadin, Nur Surayya Mohd Saudi, Wong Wai Loong
}

\begin{abstract}
Management's commitment in an organisation plays an important role in ensuring the application of effective quality management system (QMS). This article explores the relationship between management's commitment of an organisation that implements Shari'ah-based Quality Management System (MS1900:2014) with job satisfaction at Malaysian Higher Education Institution (HEI). The methodology of this study employed a qualitative design via a semi-structured interview conducted on selected respondents. The respondents consist of employees who are directly and actively involved with the implementation of MS1900 standard. The findings of this study show that management's commitment has apparently influenced job satisfaction among employees at HEI. Therefore, the results of this study can serve as a guide to ensure that the implementation of quality management system based on Shari'ah standards (MS1900) can be applied effectively, blessed and rewarded by Allah SWT.
\end{abstract}

Keywords: Management's Commitment, Shari'ah Based Quality Management System (MS1900), Job Satisfaction, Malaysian Higher Education Institution.

\section{INTRODUCTION}

In general, the implementation of quality management system (QMS) in an organisation often produce effective and positive impacts. Quality and effective terms are often associated with an effort being made to meet the needs and satisfaction of customers within an organisation, increase of productivity, and ensuring the products or services provided are best without any defect. Besides that, the quality aspect is

Revised Manuscript Received on 14 September, 2019.

* Correspondence Author

Hj. Hasan Al-Banna Mohamed*, Faculty of Management \& Defence Studies National Defence University of Malaysia (NDUM), 57000 Kuala Lumpur, Malaysia. Email: hasanalbanna@upnm.edu.my

Mohd Hamran Mohamad, Faculty of Management \& Defence Studies National Defence University of Malaysia (NDUM), 57000 Kuala Lumpur, Malaysia. Email: hamran@upnm.edu.my

Siti Arni Basir, Department of Siasah Syar'iyyah, Academy of Islamic Studies Universiti of Malaya (UM), 50603 Kuala Lumpur, Malaysia. Email: sitiarni@um.edu.my

Norlaila Mazura Mohaiyadin, Faculty of Management \& Defence Studies National Defence University of Malaysia (NDUM), 57000 Kuala Lumpur, Malaysia. Email: norlaila@upnm.edu.my

Nur Surayya Mohd Saudi,Faculty of Management \& Defence Studies National Defence University of Malaysia (NDUM), 57000 Kuala Lumpur, Malaysia. Email: nursurayya@upnm.edu.my

Wong Wai Loong,Faculty of Management \& Defence Studies National Defence University of Malaysia (NDUM), 57000 Kuala Lumpur, Malaysia. Email: wailoong@upnm.edu.my also associated with the commitment factor of the management of an organisation fulfilling their customers' needs. In fact, in Islam, the idea of perfection in the production of a product or service can be attributed to the creation of Allah SWT, such as nature, sky, earth and human. The Word of Allah SWT in Surah al-Mulk, verse 3, means:

"(And) who created seven heavens in layers. You do not see in the creation of the Most Merciful any inconsistencies. So return (your) vision (to the sky); do you see any breaks?"

Meanwhile, in Surah at-Tin, verses 4-6, Allah SWT asserts the perfection of human creation:

"We have certainly created man in the best of stature.

Then We return him to the lowest of the low. Except for those who believe and do righteous deeds, for they will have a reward uninterrupted."

Hence, the importance of quality management in daily life has become a major requirement for everyone to apply it at all times. In fact, it is achievable with the commitment of an organisation that supports and encourages the implementation of effective management system. This is because organisational commitment plays an important role in ensuring the wellbeing and satisfaction of all parties. Thus, employees will be more committed to contribute to the development and success of their organisation when the employer demonstrates unwavering support [1]. Besides that, Michalisin and White [2] emphasised that the quality of commitment and leadership in an organisation is able to produce better customer satisfaction or a better product or service.

Although a number of researchers have conducted research on the implementation of Shari'ah-based Quality Management System (MS1900:2014), studies on the relationship between management's commitment that implements MS1900:2014 with job satisfaction have never been carried out. It is clear that an in-depth study should be undertaken to examine the relationship between management's commitment in an organisation that implements Shari'ah-based Quality Management System (S-QMS) on the satisfaction of working amongst internal staff or customers. The concept of satisfaction has been outlined in the hadith of Rasulullah PBUH, which encourages his people to do a good job and always give the best for the other party. 
Among them includes the meaning of Hadith narrated by Imam al-Baihaqi RA from Saidatina Aisyah RA, which means:

"Verily, Rasulullah PBUH used to say: Allah SWT loves if someone does something in itqan or earnestly."

Even Rasulullah PBUH asserted that one does not believe unless the individual loves other people like himself (Hadith narrated by Imam al-Bukhari RA). Through the evidence of Quranic verses and the above Hadith, Rasulullah PBUH proved that the quality and commitment aspect in performing a work perfectly can produce true satisfaction in the eyes of Islam. In addition, the implementation of a work that is in accordance with the needs and requirements of Shari'ah will surely receive the blessings and pleasures of Allah SWT in the world and in the hereafter. To achieve this great goal, Malaysia introduced a special standard in the implementation of quality management systems in 2005 , focusing on product or service delivery that is in line with religious claims.

Through SIRIM Berhad, in collaboration with various companies or organisations, a special committee known as The Industry Standards Committee on Halal Standards (ISC1) was pioneered by Tun Ahmad Sarji (Former Chairman of SIRIM Berhad) [3]. Through the discussion of the committee members, the Malaysian Standard and Accreditation Council (MSDAM) approved a special standard on 18 February 2003 to be applied by companies that plan to ensure that their products and services are in line with the principles of Shari'ah requirements. Later, the quality management system standards according to Islamic perspective were implemented in 2005, and companies in Malaysia were first audited in 2010 to acquire and apply for the certification.

\section{LITERATURE REVIEW}

\section{A. Shari'ah-based System(S-QMS) \\ Quality \\ Management}

Based on past studies related to the implementation of S-QMS, there has not been much work done by scholars, particularly in terms of the relationship between management's commitment and job satisfaction in an organisation. However, S-QMS still needs a lot of spaces and opportunities that can be enhanced in organisations. Therefore, the authors will discuss the dimensions of S-QMS in detail, parallel to what every Ummah practices based on the intention of worshiping Allah SWT to produce products or services that can benefit other parties.

Management based Shari'ah is a process of doing, making and completing work or assignment through proper management function with others in order to achieve the objectives effectively [4]. In order to fulfill the aspirations, the Institute of Islamic Understanding Malaysia a.k.a. Institut Kemajuan Islam Malaysia (IKIM) in collaboration with SIRIM Berhad launched the S-QMS (MS1900) in 2005 in Malaysia, consistent with the requirements of MS ISO 9001 and has been recognised by the Jabatan Standards Malaysia [5] as shown in Figure 1.

This management system, also known as the MS1900 certification, is SIRIM Berhad's product for organisations, particularly the Higher Education Institutions (HEIs) in Malaysia that have succeeded in obtaining it through the conduct of audit. In this context, the researcher will focus on selected factors that influence successful implementation of S-QMS in Malaysian HEI, which ultimately affects the level of job satisfaction among employees of an organization.

Figure 1: Quality Management System IslamicPerspective Requirement(MS 1900:2005)

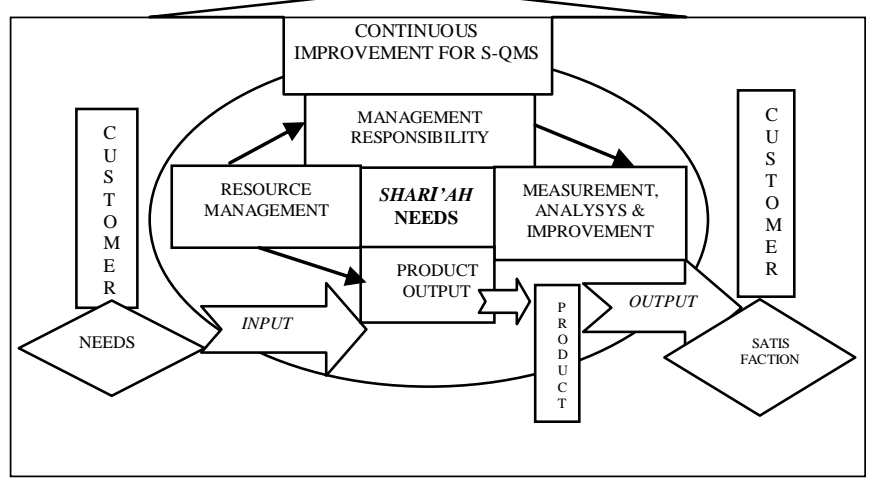

Source: Department of Standards Malaysia (2005), 3

\section{B. Management's Commitment}

Effective organisation is closely related to the leader's policies and commitment in ensuring the success of its management system. In fact, these policies and commitments need to be maintained continuously for the well-being of all parties, whether in the organisation or outside parties [6]. Thus, according to Worrall et al. [7] and Culverson [8]), a high-commitment employee tends to produce good work, such as work satisfaction, productivity improvement, decreased workplace trips, mood stability and working culture. Employees who are committed to the organisation will be more likely to contribute additional services, such as innovation and creativity that make the organisation more effective and brilliant [9]; [10].

In Islam, this term of commitment is often associated with the definition of 'Istiqamah', which means 'standing firm in the belief of true, consistent, persistent and trust' [11]. Therefore, a committed or courteous person must perform a diligent, dedicated, earnest and persistent job in order to achieve the goals or objectives set forth from the beginning. Therefore, the term commitment or 'Istiqamah' complements each other with the focus on the individual's attitude of being firm, steadfast and always working to achieve the desired aspirations.

In this regard, many past researches highlighted the relationship between top management's commitment to organisational success and excellence, such as Dimitriades [12] that stated that the commitment of management has a high positive relationship with job satisfaction. Fatima et al. [13] stated that commitment, primarily from the staff, is greatly influencing their job satisfaction. Furthermore, Chrusciel and Field [14] defined management commitment as an active and visible management body or a commitment by management organisations to achieve a certain success. This is because managers are responsible for navigating and managing members of the organisation and maintaining every quality value in line with a robust management system 
to meet its customers' needs [15]. Furthermore, the teachings of Islam emphasise on the 'Istiqamah' term as a commendable character that is encouraged to every Muslim. Through the Hadith of Rasulullah PBUH narrated by Saiditina Aisyah RA:

"Saiditina Aisyah RA reported that Rasulullah PBUH had said the best deeds in the sight of Allah SWT is that which is performed continuously, even though small in quantity."

Therefore, this commitment or Istiqamah practice is a key requirement in an organisation that must be practiced by all employees in order to demonstrate their level of performance and productivity to achieve organisational goals. Generally, the researchers found that the top management's commitment factor in an organisation plays a critical role in a successful implementation of S-QMS so that the employees are always happy to perform tasks entrusted to him or her.

\section{Job Satisfaction}

All submitted paper should be cutting edge, result oriented, original paper and under the scope of the journal that should belong to the engineering and technology area. In the paper title, there should not be word 'Overview/brief/ Introduction, Review, Case study/ Study, Survey, Approach, Comparative, Analysis, Comparative Investigation, Investigation'.Job satisfaction in an organisation has become a popular issue among scholars. Job satisfaction is an attitude that is formed within each individual and affects the implementation of quality organisation management system and gives the best impact to their daily lives. This is confirmed by Gary et al. [16] who stated that customer satisfaction is very important as it relates directly to the results of an organisation, but staff satisfaction tends to work more seriously [17].

Therefore, to ensure that the level of satisfaction of external customers is at a high level, the management must ensure that the internal customer, in this study refers to the staff, is not neglected. This is because employees are the most important asset in an organisation that must be prioritised [18]. Furthermore, Lee et al. [19] has proven that it is essential for organisations to produce high-quality products or services at a competitive cost to satisfy customers.

Furthermore, the job satisfaction issue is closely related to the implementation of a perfect organisational management system and is able to provide pleasure, while giving a greater commitment. Therefore, this study will focus on management's commitment factors that provide job satisfaction among staff in HEIs that implement S-QMS through MS1900 standards in Malaysia.

\section{METHODOLOGY}

This study adopted the qualitative research, which refers to case study as suggested by Stake [20]. The selected respondents involved the academic and non-academic staff of the Public and Private Universities in Malaysia, which have successfully implemented S-QMS. The researchers also used semi-structural interviews, direct observation and analysis of documentary evidence as the primary data collection method. The advantages of using various data collection methods were emphasised by Van Maanen [21] as a technique for cross validation between two or more different methods, as well as to provide triangulation and strengthening the validity of data collection of this study and not only depending on one technique. This is consistent with Bernard and Ryan [22] that stated that respondents are specifically able to provide more comprehensive, clear, accurate and in-depth researches on subject matters under study. All selected respondents were directly and actively involved in the implementation of S-QMS (MS1900).

In order to obtain permission from the respondents, the researchers contacted each respondent for an interview session. This is because according to Bogdan and Biklen [23], the entry and acceptance of the respondents should be resolved in advance as it can lead to a major problem in the future. 11 respondents were selected as interviewees which consist of three different categories that non-academic staff, academic staff and top management. The involvement of respondents from the three different categories allowed researchers to gain a broader and comprehensive view of the implementation of MS1900 in the case study involved.

The researchers also made direct observations at the site of the study by taking notes, photographs and verbatim statements (i.e. direct-fractional statements) by writing as many memos as possible in collecting related information as stated by Marohaini [24]. Secondary sources are derived from evidence of supporting documents and records that contain important information relevant to this study, such as letter, memorandum, official statement (agenda, announcement, meeting minutes, written reports), administrative documents (proposal, progress reports), internal documents and materials published in the mass media.

\section{A. Results and Findings}

The researchers transcribed the interview between researchers and respondents using the coding process using the NVivo ${ }^{\mathrm{TM}}$ software. The researchers found that the management's commitment factor was influencing job satisfaction when implementing S-QMS (MS1900) at Public University. Table 1 shows that the total amount of reference code for Private University is 59 for the management's commitment factor.

Table- I: Coding Process towards 'Management's Commitment' in Private University

\begin{tabular}{|c|c|c|}
\hline Respondent & $\begin{array}{c}\text { Total Number of } \\
\text { Respondent }\end{array}$ & $\begin{array}{c}\text { Total Number of } \\
\text { Reference Code }\end{array}$ \\
\hline Non-academic Staff & 5 & 33 \\
\hline Academic Staff & 3 & 15 \\
\hline Top Management & 3 & 11 \\
\hline Total & 11 & 59 \\
\hline
\end{tabular}

Source: ‘Coding Query’ NVivo ${ }^{\mathrm{TM}}$ Analysis

Table 2 presents the coding process analysis for Public University. 20 reference codes were coded from non-academic staff, nine reference codes were coded from academic staff and eight reference codes were coded from the top management.

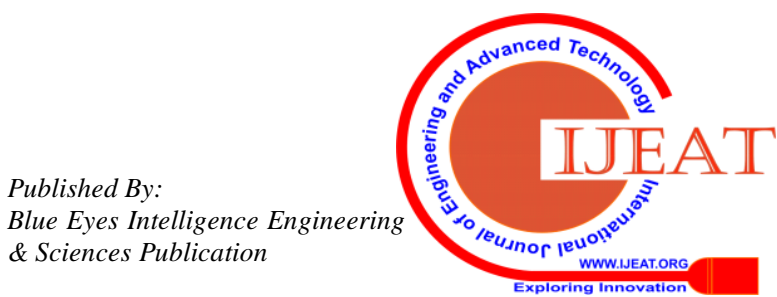


Table- II: Coding Process towards 'Management's Commitment' in Public University

\begin{tabular}{|c|c|c|}
\hline Respondent & $\begin{array}{c}\text { Total Number of } \\
\text { Respondent }\end{array}$ & $\begin{array}{c}\text { Total Number of } \\
\text { Reference Code }\end{array}$ \\
\hline Non-academic Staff & 4 & 20 \\
\hline Academic Staff & 3 & 9 \\
\hline Top Management & 2 & 8 \\
\hline Total & 9 & 37 \\
\hline
\end{tabular}

Source: 'Coding Query’ NVivo ${ }^{\mathrm{TM}}$ Analysis

Researcher found that the top management's commitment in implementing S-QMS (MS1900) cannot be denied as the top management from the Vice Chancellor, Deputy Vice-Chancellors and Heads of Department together with the stakeholders, fully supported the implementation of MS1900. This is because the success of planned programmes or quality of activities requires for the commitment and support from the top management. This further reflects that the top management is commited with a budget, which is often approved by the Centre for Quality Management in their organisation to implement MS1900 programmes annually.

Additionally, one of the respondents of this study, a finance officer in a university, stated that the management was always 'going downhill' and participating in workshops or courses organised by the Centre for Quality Management. Their participation in workshops or courses is very useful for the organisation, such as proposing ideas and insights to review documents or improve the quality of procedures. Indirectly, staff will enjoy working with them. In fact, other respondents, such as academic staff and a former Shari'ah officer of a university, mentioned that the leader is considered as a role model for the staff as a whole or otherwise, all planning and implementation of S-QMS (MS1900) will be introverted.

Among the clear evidences mentioned by one of the respondents of this study, a Quality System Officer at Public University, include:

"I saw that the self-sufficiency provided by the top management such as commitment given by the Director to the staff. If the Director has come, staff will enjoy".

In fact, the importance of commitment and support from the top management is also shared by academic and non-academic staff. They agree that management's commitment is one of the driving factors to ensure that the implementation of MS1900 system is smooth and perfect. Overall, when referring to the results of this study, it is found that all respondents indicated that their leaders are very supportive with the implementation of S-QMS (MS1900). This is consistent with the findings by Gamboa and Melao [25] and Sany Sanuri et al. [26], who found that the management's commitment is very important, being a catalyst and critical role to ensure successful implementation of quality management systems within the organisation, which ultimately satisfies their own employees.

\section{CONCLUSION}

In conclusion, the findings of this study prove that the management's commitment in implementing quality management system, especially MS1900 standards in an

organisation, is highly relevant and has a significant positive relationship. Hence, the overall management's commitment in ensuring the implementation of this standard system ultimately affects the employees in an organisation in terms of satisfaction with the management and accountability to the organisation. Ultimately, the success of outward or materialistic aspects will result in the achievement of consideration or spiritual with true success (al-Falah) among members of the organisation. This present study contributes to the body of knowledge by providing insight about the effect ofmanagement's commitment to job satisfaction in the context of MS1900 implementation. This study has also given apparent explanation concerning MS1900 implementation within higher education environment.

\section{REFERENCES}

1. Karia, N, and Asaari, M. "The effects of total quality management practices on employees' work-related attitudes,'The TQM Magazine vol. 18 , no. 1,2006 , pp. $30-43$

2. Michalisin, M.D, and White, G.P. "An empirical study of the posturing implementation gap in quality management,"Quality Management Journal,vol. 8, no. 1, 2001, pp. 34-51.

3. Siti Arni, B. "The establishment and requirements of Malaysian quality management system MS1900 from Islamic perspective," Prosiding Persidangan Antarabangsa Islam dalam Masyarakat Malaysia (PAIMM), Prakata: Arba'iyah Mohd. Noor, Jabatan Sejarah dan Fakulti Sastera dan Sains Sosial, Universiti Malaya, KL, 5-6 October2010, 2, p 347

4. Norfazila, I. "Sistem pengurusan Islam alternatif terbaik," Berita Harian, 5 June 2012, p. N6.

5. Jabatan Standards Malaysia. "Quality management systems Requirements from Islamic perspectives (MS1900:2005)," Selangor: SIRIM Berhad, 2005.

6. PM. Haika Khazi. "Nasional: BN tak buat janji mustahil," Berita Harian, 5 June 2012, p. 2.

7. Worrall, L., Cooper, C.L., and Campbell-Jamison, F. "The impact of organizational change on the public sector managers,"Personnel Reviews, vol. 29, no. 5, 2000, pp. 613-636.

8. Culverson, E.D. "Exploring organizational commitment following radical change: A case study within the Parks Canada Agency," Master Thesis of Arts in Recreation and Leisure Studies. Canada: University of Waterloo, Ontario,2002.

9. Bennett, H., and Durkin, M. "The effects of organisational change on employee psychological attachment: An exploratory study,"Journal of Managerial Psychology, vol. 15,no. 2, 2000, pp. 126-146

10. Asri, M., and Hamrila A.L. "Faktor-faktor yang mempengaruhi komitmen pekerja di organisasi awam,”Jurnal Kemanusiaan, vol. 10, December2007, pp. 56-64.

11. Ensiklopedia Islam. Jld. ke-5. Kuala Lumpur: Malaysian Encyclopedia Research Center Bhd., 1998, pp. 166-167, entry "Istiqamah".

12. Dimitriades, Z. S. "Customer satisfaction, loyalty and commitment in service organizations: Some evidence from Greece," Management Research News, vol. 29, no. 12, 2006, pp. 782-800

13. Fatima, J.K., Abdur Razzaque, M., and Mascio, R.D. "Modelling roles of commitment on rapport and satisfaction,"International Journal of Bank Marketing,vol. 33, no. 3, 2015, pp.261-275.

14. Chrusciel, D., and Field, D.W. "From critical success factors into criteria for performance excellence - An organizational change strategy,"Journal of Industrial Technology, vol. 19, no. 4, 2003,pp. 2-11.

15. Muhammad Madi, A., Zainal Ariffin, A. and Azman, I. "The importance of soft factors for quality improvement: Case study of electrical and electronics firms in Malaysia," International Journal of Business and Management, vol. 3, no. 12, 2008, pp. 60-69.

16. Gary, J.H., Desten, I.L., and Sarros, J.C. "A matter of size: Does organizational culture predict satisfaction in small organizations?". Paperwork, 65/03, Faculty of Business \& Economics, Monash University, Australia, September2003, p. 2

17. Mathis, R. L., and Jackson, J. H. "Human resource management," Australia: South-Western College Publishing, 2006.

18. Chen, S.H., Yang, C.C., Shiau, J.Y., and Wang, H.H. "The development of an employee satisfaction model for higher education,"The TQM Magazine, vol. 18, no. 5, 2006, pp. 484-500. 
19. Lee, C. C., Yang, J., and Yu, L. M. "The knowledge value of customer and employees in product quality,'Journal of Management Development, vol. 20, no. 8, 2001, pp. 691-704.

20. Stake, R. E. "Case study methods in educational research: Seeking sweet water," in Complementary Research Methods for Research in Education.Richard M. Jaeger,Ed. Washington, DC: American Educational Research Association, 1997.

21. Van Maanen, J. “Qualitative methodology,” Beverly Hills, California: SAGE, 1983.

22. Bernard, H.R., and Ryan, G.W. "Analyzing qualitative data: Systematic approaches," Thousand Oaks, California: SAGE Publications, Inc., 2010

23. Bogdan, R. C., and Biklen, S. K. "Qualitative research for education: An introduction to theories and methods," (5th ed.). 2007, UK: Pearson Education

24. Marohaini, M. Y. "Penyelidikan kualitatif, pengalaman kerja lapangan kajian,” Kuala Lumpur: Universiti Malaya, 2001.

25. Gamboa, A. J., and Melao, N. F. "The impacts and success factors of ISO 9001 in education: Experiences from Portuguese vocational schools," International Journal of Quality \& Reliability Management vol. 29, no. 4, 2012, pp. 384-401.

26. Sany Sanuri, M.M., Nur Adiana Hiau, A., Nordin, K., and Mohd Idzwan, Y. "Sustaining a quality management system: Process, issues and challenges,"Business Strategy Series, vol. 14, no. 4, 2013,pp. 123-130.

\section{AUTHORS PROFILE}

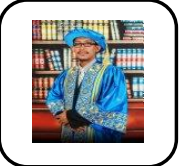

Associate Professor Dr. Hj. Hasan Al-Banna bin Mohamed, Associate Professor at Department of Human Resource Management, National Defence University of Malaysia. He has awarded Bachelor in Islamic Education (UM, 1996), Master of Science in Human Resource Development (UNIMAS, 2001) \& PhD in Islamic Quality Management (UM, 2015). He has been teaching in UPNM since 2006. He has conducted various research in related to his expertise like HRM, Islamic Quality Management and Islamic Education. He has published many articles, book and chapter in books in his areas internationally and locally. $\mathrm{He}$ also has received numerous research awards in innovation exhibitions such as PECIPTA, MTE, ITEX, i-INNOVA, IID and PERINTIS. He is also member for the professional body namely Malaysian Institute of Human Resource Management; ISDS Japan, and associate member in Akademi Professor Malaysia.

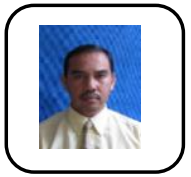

Dr. Mohd Hamran Mohamadis now a Senior Lecturer of Faculty of Defence Studies and Management, National Defence University of Malaysia. He has Bachelor Degree in Management (Technology) from UTM (1994) and Master of Business Administration from UUM (2007). In 2016, UUM also awarded him a PhD in Human Resource Management. His $\mathrm{PhD}$ research is related to the area of human resource management practices and good governance in enforcement based organization. He has involved in teaching and lecturing since 1997 and conducting various researches related to HRM practices, leadership, good governance and green technology. Besides, he has also published more than 20 articles in peer reviewed and indexed journals as well as proceedings. Presently, he is an editor for the International Journal of Accounting, Finance and Business and International Journal of Global Business and Socia Entrepreneurship. He was part of the reviewers of SCOPUS indexed journal namely 'Jurnal Pengurusan' owned by the UKM. He was many times appointed as a conference moderator at the international conferences organized by the Global Academy Excellence. As a member of the competition for Shari'ah Based Quality System (MS 1900), his group was selected as the Top 10 Finalist of National Innovation Awards Competition by the Ministry of Sciences and Technology. He is also a member for the professional body namely Malaysian Institute of Human Resource Management, Persatuan Sosial Sains Malaysia and associate member ofHimpunan Anak Kedah Malaysia.

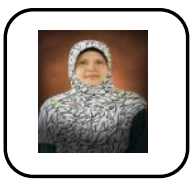

Associate Professor Dr. Siti Arni Basiris an Associate Professor at Department of Siasah Syar'iyyah, Academy of Islamic Studies, University of Malaya. She have awarded Bachelor in Economics (UM, 1995), Master in Public Administration (UM, 1997) \& PhD in Quality Management System ISO 9000 (University of Salford, 2008). She has been teaching in UM since 1998. She has conducted various research in related to her expertise like ISO 9000, Shariah-based (Halal) quality system MS1900 and governance. The focus of her research is on soft factors, issues $\&$ works ethics in quality management practices. She have selected higher education, public services, GLCs, city council and Islamic administrative institutions as case studies. She has published 15 articles in high impact journals (SCOPUS \& ISI indexed) and 4 books. She is an article reviewer for prestigious national and international publishers like UM, USM, DBP, Routledge and Emerald Thompson. The manual of Halal Quality System of MS1900 she developed have selected as the Top 10 Finalist of National Innovation Awards Competition organised by Ministry of Science and Technology, MOSTI.

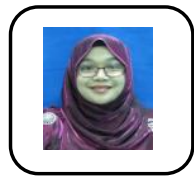

Norlaila Mazura Mohaiyadinis one the lecturers in National Defence University of Malaysia since 2015 until present in the field of accounting and finance. She has previously held appointments as a lecturer in two higher education institutions and she has been nominated as one of the best lecturer awards at the national level in 2015, organised by Chartered Institute of Management Accountants. In research wise, she has published more than twenty papers in multi and cross-disciplines in SCOPUS journals, ERA journals, indexed journals and conference proceedings.

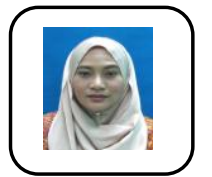

Dr. Nur Surayya Mohd Saudiwas a Financial Analyst in the top 3 Banks in Malaysia and possess a vast experience in Banking and Finance. Surayya currently works at Department of Logistics Management and Administration, Faculty of Defence Studies and Management at National Defence University of Malaysia.She has awarded $\mathrm{PhD}$ is in Financial Economics from Universiti Malaysia Sabah, Master of Economics from Universiti Malaysia Sabah and Bachelor in Accounting from Universiti Teknologi Mara. Her research areas are Financial Economics, Defence Economics, International Economics, Human Resource in Economics, Leaderships study and Islamic Quality Management. She is the Economics module convener for National Resilience Defence College, Malaysia. Her current project is to study the effect of military expenditure in ASEAN 10 economies. Surayya actively involved in Corporate Social Responsibility nationally and Internationally. She also an active member for Malaysia Economic Association (MEA). Besides, she is the reviewer for International Journal of Advanced Research in Economics and Finance (IJAREF)

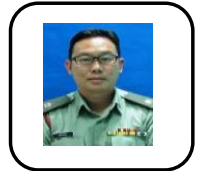

Major Ts. Wong Wai Loongis a graduate with Diploma in Strategic and Defence Studies (University of Malaya), BSc in Computer Engineering (University Technology of Malaysia) and MSc in Engineering Business Management (University of Warwick) Currently, Major Ts. Wong is pursuing his Doctorate in Resource Management at National Defence University of Malaysia. Presently, he is a Senior Lecturer at Department of Logistics Management and Administration, Faculty of Defence Studies and Management at National Defence University of Malaysia. $\mathrm{He}$ is also an active speaker/moderator/facilitator at seminars and conferences on logistics, quality management and leadership. Major Ts. Wong is a qualified Professional Technologist (Ts) in Transportation \& Logistics Technology and he also a Chartered Member in The Chartered Institute of Logistics and Transport in Malaysia (CILTM). 